\title{
Gene Profile Analysis and Molecular-Physiological Evaluation of Tomato Genotypes Under Drought Stress
}

\author{
Rahele Ghanbari Moheb Seraj ${ }^{1, *}$, Masoud Tohidfar ${ }^{2, *}$ and Asadollah Ahmadikhah ${ }^{2}$ \\ 1 Department of Horticultural Sciences, Faculty of Agriculture and Natural Resources, University of Mo- \\ haghegh Ardabili, Ardabil, Iran; r.ghanbari@uma.ac.ir \\ 2 Department of Plant Biotechnology, Faculty of Life Sciences and Biotechnology, Shahid Beheshti University, \\ Tehran, Iran; a_ahmadikhah@sbu.ac.ir \\ * Correspondence: m_tohidfar@sbu.ac.ir
}

\begin{abstract}
Identification of the differentially-expressed genes is important for clarification of the complex molecular mechanisms under drought conditions. In this experiment, transcriptome profiles of sensitive and tolerant tomato genotypes under drought stress were analyzed. Three up-regulated genes were selected, included CAB3 (Chlorophyll a-b binding protein3), SAMDC (S-adenosylmethionine decarboxylase proenzyme), and ACS9 (1-aminocyclopropane-1-carboxylate synthase 9). After bioinformatics analysis, tomato genotypes were subjected to drought stress and gene expression was determined using Real-Time-PCR. Physiological parameters of genotypes were also measured by spectrophotometer-based methods. According to the results, these three genes play a key role in stress tolerance. Expression of the CAB3 gene in both sensitive and tolerant genotypes was not significantly different compared to the control, but the SAMDC gene decreased in both genotypes and the ACS9 gene decreased in sensitive genotype and increased in tolerant genotype. The physiological analysis also showed that under stress conditions, the photosynthetic system of the plant was disrupted and the chlorophyll content was reduced, but, proline content and antioxidant enzymes activity increased, in which their quantity in the tolerant genotype was significantly higher than sensitive. Under drought stress, due to damage to the lipid membrane, Malondialdehyde content also increased, in which the sensitive genotype was more affected.
\end{abstract}

Keywords: Bioinformatics analysis; Drought stress; Gene expression; Physiological parameters; Tomato; Transcriptome.

\section{Introduction}

Water deficit represents a major global abiotic stress that limits plant productivity by inhibiting plant growth and development [1]. Plants, as sessile organisms, have developed different systems to survive under undesirable and fluctuating stress conditions, such as drought avoidance, escape and tolerance [2]. The germplasm of most of the cultivated crops contains several unknown drought stress tolerant genes. Besides, many reports indicated the wild species of most modern cultivars possess abiotic stress tolerance genes [3]. Therefore, characterize the differentially expressed genes is important to the clarification of the complex molecular mechanisms under drought conditions in wild and agronomic plants [4]. In addition to genes, physiological parameters are also affected by drought stress. Some physiological changes induced by drought include chlorophyll, proline, antioxidant enzymes [5], and high production of reactive oxygen species (ROS) in cells, which causes cell damage and plant death [6]. Tomato is an economically important crop worldwide, which is sensitive to a series of abiotic stresses, especially drought [7], and is a plant that requires a large amount of water for its development [8]. Adequate genetic variation for abiotic stress tolerance exists within the cultivated tomato (S. lycopersicum), as well as in its related wild species such as S. pimpinellifolium [9]. Despite their 
wide natural variation, rather limited efforts have been devoted to identifying these variations in tomato to produce drought-tolerant cultivars [10]. Therefore, in this study, we identified candidate genes in tomato genotypes under drought stress through transcriptome analysis. We then examined the expression of these genes under water stress using real-time PCR. Finally, to further confirm, we also measured some important physiological traits and compared them with gene expression.

\section{Materials and Methods}

2.1. Identification of candidate genes

Transcriptome profiles of sensitive (Solanum lycopersicum) and tolerant (Solanum pimpinellifolium) tomato genotypes under control and water deficit conditions were obtained from GEO, accession number GSE39894. The data were analyzed using the GEO2R program and the expression ratio of treated genes to control genes was calculated and determined by $\log$ FC. Then, the probes with log FC above +2 and below -2 were selected. Subsequently, the probe sequences were received from the PLEXdb site and BLAST was performed on them. Then, the most similar sequence accession was obtained and using the NCBI or UniProt database, its UniGene code was determined and recorded. At the same time, this sequence was also BLAST at the TAIR site and Arabidopsis UniGene was also received. This operation was conducted for all probes. Heat map analysis was used to compare the expression of the genes, that this analysis was performed using $\mathrm{R}$ software and the pheatmap package. The functional category was determined by ShinyGO v0.61 and comparing gene lists was performed by Venny 2.1.0 program. The program STRING was used to determine the interaction of proteins, in which the UniGene codes of Arabidopsis were introduced into the program, then the node1 and node 2 data were saved and used to plot the gene network by Cytoscape software. The gene network was plotted using the CytoHubba plugin, based on three MNC, Degree, and Closeness algorithms. Finally, the networks obtained from the three algorithms were compared and the genes with the highest interaction were selected.

\subsection{Bioinformatics analysis of genes}

KEGG database was used to study the photosynthetic pathway and metabolism of selected genes. The location of protein activity and placement was determined using the online software WOLF PSORT and Target $\mathrm{p}$, respectively. Gene expression changes in different plant tissues and developmental stages of tomato were investigated using Genevestigator software. The stability and instability, hydrophobicity, and isoelectric point of the proteins encoded by these genes were distinguished using the Protparam server software. The enzymatic reactions and enzyme products and reaction pathways were determined using the BRENDA database.

\subsection{Molecular experiments}

2.3.1. Plant material and stress treatment

The seeds of two tomatoes (sensitive and tolerant) genotypes were prepared from the company of Pakanbazr, Isfahan, Iran. Seeds were surface sterilized with an aqueous solution of $70 \%$ ethanol for $30 \mathrm{sec}$ and $30 \%$ Sodium hypochlorite for $5 \mathrm{~min}$ and finally washed with sterile distilled water 2-3 times. For in vitro germination, seeds were cultured in the MS (Murashige and Skoog) medium with vitamins, sucrose $(3 \% \mathrm{w} / \mathrm{v})$, and solidified with $0.6 \%$ Agar (Merck, Germany). Before autoclaving at $121{ }^{\circ} \mathrm{C}$ for $20 \mathrm{~min}$, the $\mathrm{pH}$ of the medium was set to 5.8 . All of the cultures were maintained at $25^{\circ} \mathrm{C}$ with a photoperiod of $16 \mathrm{~h}$ using a photosynthetic photon flux density (PPFD) of $40 \mu \mathrm{mol} \mathrm{m}-2 \mathrm{~s}-1$ provided by cool white fluorescent lamps for 30 days. After germination and reaching the four-leaf stage, the plantlets transferred to pots containing perlite and covered with polyethylene bags and were irrigated every day for 8-10 days and were kept in the culture room with the above condition. The covers were gradually removed and plants were transferred to large pots comprising garden soil for 20 days.

Then 6-8 leaf seedlings were transferred to field conditions. The field site is located in Shahid Beheshti University, Tehran, Iran $\left(51.23^{\circ} \mathrm{N}, 35.48^{\circ} \mathrm{E}\right.$, and $1769 \mathrm{~m}$ above mean sea 
level). Air temperature and relative humidity were recorded from the meteorological site (Table1). The soil composition consisted of $1 / 3$ clay, $1 / 3$ sand, and $1 / 3$ leaf composts. The field area was $70 \mathrm{~m} 2$. Furrows were created to implement this study. The space of plants on rows was $1 \mathrm{~m}$ and between rows was $1 \mathrm{~m}$. In general, 7 furrows were created and cultivation was performed as follows: Treated plants of tolerant genotype, empty furrow, control plants of tolerant genotype, empty furrow, treated plants of sensitive genotype, empty furrow, and control plants of sensitive genotype. 10 plants were cultured on each furrow, so the total number of plants cultivated on the field was 40. After 20 days (before the flowering stage), drought stress was applied to the plants, in which the plants were subjected to drought stress (without irrigation) for 5 days, but control treatments were irrigated by the previous method [11]. Then, at 9 a.m., the medium-sized intact leaves were separated from the middle part of the plant stem and placed in sterile foil and transferred to a -80 freezer. The number of replicates for each treatment was 3 replicates. The collected samples were used for molecular and physiological measurements.

Table1. Different growth stages of tomatoes along with the exact date and average temperature and humidity of the growing environment

\begin{tabular}{cccc}
\hline Stages & Start date & Average temperature & Average humidity \\
\hline Seedling & 2018.06 .22 & $25^{\circ} \mathrm{C}$ & $50 \%$ \\
Vegetative & 2018.07 .23 & $25^{\circ} \mathrm{C}$ & $50 \%$ \\
Budding & 2018.08 .23 & $26.1^{\circ} \mathrm{C}$ & $25 \%$ \\
\hline Initiation of drought stress & 2018.09 .06 & $26.1^{\circ} \mathrm{C}$ & $25 \%$ \\
Sample collection & 2018.09 .11 & $26.1^{\circ} \mathrm{C}$ & $25 \%$ \\
\hline
\end{tabular}

\subsubsection{Primer Design}

After selecting the genes, their nucleotide sequences were obtained from the NCBI site and then BLAST was performed. Next, high-similarity sequences were selected and aligned using T-Coffee software. From the conserved areas, near the end of poly adenine, primer design was performed. The Polymerase Chain Reaction (PCR) product length was considered to be between 150 to 250bp. Homodimer, heterodimer, stem-loop, GC percent, and TM temperature were measured using Vector NTI and Oligo7 software. The primers were then synthesized at Bioneer Company of South Korea. Primer sequences of the candidate genes, as well as the housekeeping gene, are demonstrated in Table 2.

Table 2. Primer sequence of candidate and housekeeping genes.

\begin{tabular}{ccccc}
\hline $\begin{array}{c}\text { Primer } \\
\text { Name }\end{array}$ & Primer Sequence & $\begin{array}{c}\text { PCR Product } \\
\text { Length(bp) }\end{array}$ & TM & $\begin{array}{c}\text { PCR Amplifica- } \\
\text { tion Efficiency }\end{array}$ \\
\hline ACS9 & F:ATGCGACATCTACTAAGTTCC & 152 & 57 & 1.83 \\
& R:GATTCTGGTGATTAGTTGCGTTG & & 61 & \\
SAMD & F:TGAACCTGCCGATGCCAATAATGTG & 140 & 66 & 1.99 \\
& R:GCTCTGAAATCGTAACCCACTGCT & & 65 & \\
CAB3 & F:GTAATGGTGTCAAGTTCGGTGAG & 157 & 63 & 2.05 \\
& R:GGTCTTCAGCAAGGCCTAATG & & 61 & \\
18 SrRNA & F:ATGATAACTCGACGGATCGC & 200 & 56.7 & \multirow{2}{*}{1.97} \\
& R:CTTGGATGTGGTAGCCGTTT & & 57.2 & \\
\hline
\end{tabular}


Total RNA of each sample was isolated from approximately $0.2 \mathrm{~g}$ of fresh leaves using a total RNA kit (RB1001, RNA, Iran). After RNA extraction, gel electrophoresis (1\% Agarose) was used to visually assess the quality of extracted RNA. Before cDNA synthesis, RNA treated with DNase I (RB125A, RNA, Iran) to remove any genomic DNA contamination. Subsequently, the first-strand cDNA was synthesized in a $20-\mu \mathrm{L}$ reaction mixture (RB125A, RNA, Iran) following the manufacturer's instructions. After cDNA synthesis, PCR was performed using the primers, and products were visualized by agarose gel electrophoresis.

\subsubsection{Gene expression analysis}

Quantitative Real-Time PCR amplification was performed in 48-well plates with an Applied Biosystems ${ }^{\mathrm{TM}}$ StepOne ${ }^{\mathrm{TM}}$ Real-Time PCR System (Applied Biosystems, CA, USA) using SYBR ${ }^{\circ}$ Green Real-Time PCR Master Mix (RB120, RNA, Iran). PCR reactions were prepared in $20 \mu \mathrm{L}$ volumes containing: $1 \mu \mathrm{L}$ of synthesized cDNA, $10 \mu \mathrm{L} 2 \times$ SYBR, $1 \mu \mathrm{L}$ of 1:20 diluted each primer, and $7 \mu \mathrm{L}$ deionized water. The reactions consisted of an initial step of $95^{\circ} \mathrm{C}$ for $5 \mathrm{~min}$, followed by 40 denaturation cycles at $95^{\circ} \mathrm{C}$ for $1 \mathrm{~min}$ and primer annealing at $62^{\circ} \mathrm{C}$ for $1 \mathrm{~min}$ (for all genes). Next, the melting curves ranging from $60^{\circ} \mathrm{C}$ to $95^{\circ} \mathrm{C}$ were evaluated in each reaction to investigate the specificity of the amplicons. Biological triplicates of all samples were used for the qRT-PCR analysis, and three technical replicates were applied for each biological sample. The threshold cycle $(\mathrm{Ct})$ was calculated using the 2- $\triangle \triangle \mathrm{Ct}$ method [12]. Efficiency and cycle threshold values were computed using the LinRegPCR quantitative PCR data analysis program [13], and relative expression levels were computed using the REST method [14].

\subsection{Physiological experiments}

\subsubsection{Chlorophyll $\mathrm{a}, \mathrm{b}$ and $\mathrm{a}+\mathrm{b}$}

Chlorophyll $\mathrm{a}$ and b content were determined according to Arnon [15] and Mackinney [16] methods, respectively. A total of $0.2 \mathrm{~g}$ of a plant sample was added to $2 \mathrm{~mL}$ of $80 \%$ acetone and grounded to a homogenate. Then, the solution volume with acetone $8 \%$ reached $25 \mathrm{ml}$ and centrifuged at 4,000 rpm for $10 \mathrm{~min}$. The absorbance of the solutions was recorded at 646 and $663 \mathrm{~nm}$ and their amount was calculated using the following equations.

chla $(\mathrm{mg} /(\mathrm{g} \mathrm{FW})=(12.25(\mathrm{~A} 663)-2.55(\mathrm{~A} 646)) \times \mathrm{VW}) \times 100$

$\mathrm{chlb}(\mathrm{mg} /(\mathrm{g} \mathrm{FW})=(22.31(\mathrm{~A} 646)-4.91(\mathrm{~A} 663)) \times \mathrm{VW}) \times 100$

$\% \mathrm{v} / \mathrm{w}=($ weight of solute $($ in $\mathrm{g})) /($ volume of solution $($ in $\mathrm{mL})) \times 100$

\subsubsection{Proline content}

Proline content was extracted from a sample of $0.5 \mathrm{~g}$ fresh leaf material samples in $3 \%(\mathrm{w} / \mathrm{v})$ aqueous sulphosalicylic acid and estimated using the ninhydrin reagent according to the method of Bates et al. [17]. The absorbance of the soluble was measured at 520 $\mathrm{nm}$ using a spectrophotometer. A calibration curve was created with the proline as a standard. Finally, the proline content was measured by the following equation: Proline $((\mu \mathrm{mole})(\mathrm{gr}$ of fresh weight $)=($ proline $(\mu \mathrm{g} / \mathrm{ml}) \times$ toluene $(\mathrm{ml})) /(115.5 \mu \mathrm{g} / \mu \mathrm{mole}) /(\mathrm{g}$ sample)/5)

\subsubsection{Malondialdehyde (MDA)}

Lipid peroxidation was specified by the Stewart and Bewley [18] method. $0.5 \mathrm{~g}$ of leaf sample was homogenized in $4 \mathrm{ml}$ of $1 \%(\mathrm{w} / \mathrm{v})$ trichloroacetic acid (TCA), and then centrifuged at $15,000 \mathrm{~g}$ for $10 \mathrm{~min}$. Then, $4 \mathrm{ml}$ of $0.5 \%(\mathrm{w} / \mathrm{v})$ TBA in $20 \%(\mathrm{w} / \mathrm{v})$ TCA was added to $2 \mathrm{ml}$ of the supernatant. The mixtures were heated at $95^{\circ} \mathrm{C}$ for $30 \mathrm{~min}$ and then quickly cooled in an ice bath. Finally, the mixture centrifuged at $10,000 \mathrm{~g}$ for $10 \mathrm{~min}$, then the absorption of samples was read at $532 \mathrm{~nm}$ and the quantity of nonspecific absorption was read at $600 \mathrm{~nm}$ and subtracted from ABS 532. The MDA content was measured by the extinction coefficient of $155 \mathrm{~cm}-1 \mathrm{mmol}-1$.

2.4.4. Antioxidant enzymes

a. Preparation of leaf enzyme extract 
Fresh leaves $(0.2 \mathrm{~g})$ were homogenized in $1200 \mu \mathrm{l}$ of $0.2 \mathrm{M} \mathrm{Na}$-phosphate buffer $(\mathrm{pH}$ 7.8) containing $0.1 \mathrm{mM}$ EDTA. Then, the homogenate was centrifuged at $15000 \mathrm{~g}$ for $20 \mathrm{~min}$ at $4{ }^{\circ} \mathrm{C}$. The supernatant was used for APX and CAT activity assay. To avoid enzyme inactivation all procedures for enzyme extraction and activity determination were carried out on ice bath.

b. Ascorbate peroxidase (APX)

The activity of the APX enzyme was measured by Nakano and Asada [19] method. The reaction mixture contained $100 \mu \mathrm{l}$ potassium phosphate buffer $1 \mathrm{M}(\mathrm{pH} 7.8), 50 \mu l$ hydrogen peroxide $10 \mathrm{mM}$ and $50 \mu \mathrm{l}$ ascorbate $10 \mathrm{mM}$, and $10 \mu \mathrm{l}$ enzyme extract, in a total volume of $1 \mathrm{~mL}$. The reaction was started by adding $\mathrm{H} 2 \mathrm{O} 2$ and performed at $25^{\circ} \mathrm{C}$. The oxidation rate of ascorbate was determined by the decrease in absorbance at $290 \mathrm{~nm}$ for 3 min. Reaction mixture without enzymatic extracts was used as a spectrophotometer blank. Finally, the activity of the enzyme was calculated using the following equation: Enzyme activity $($ Units $/ \mathrm{L})=((\Delta$ Abs $\times$ Total assay volume $)) /((\Delta \mathrm{t} \times \varepsilon \times 1 \times$ Enzyme sample volume $))$

Where $\Delta \mathrm{t}$ is the time of incubation (min), $\Delta \mathrm{Abs}$ is the change in absorbance, $\varepsilon$ is the extinction coefficient of substrates $(2.8 \mathrm{M}-1 \mathrm{~cm}-1)$, and 1 is the cuvette diameter $(1 \mathrm{~cm})$. Enzyme activity (Unit) was defined as the amount of enzyme that oxidized $1 \mu \mathrm{mol}$ of substrate/min.

c. Catalase enzyme (CAT)

The activity of CAT was determined by Bergmeyer [20] method. The reaction mixture contained, $0.01 \mathrm{M} \mathrm{H} 2 \mathrm{O} 2$ and $0.05 \mathrm{M}$ potassium phosphate buffer $\mathrm{pH} 7.0$ in a total volume of $1 \mathrm{~mL}$. The reaction was initiated by the addition of $20 \mu \mathrm{L}$ enzyme and the rate of utilization of $\mathrm{H} 2 \mathrm{O} 2$ was measured for an initial $3 \mathrm{~min}$ by measuring a decrease in absorbance at $240 \mathrm{~nm}$. Reaction mixture without enzyme extract was used as a control:

$\mathrm{A}=\left(\left[\Delta \mathrm{A} \rrbracket \_240 \times \mathrm{df} \times 1000 \times 2\right) / \mathrm{et}\right.$

$\mathrm{A}=$ Specific activity of enzyme according to $\mu \mathrm{M}$ decomposed $\mathrm{H} 2 \mathrm{O} 2$ in one minute and one $\mathrm{ml}$ of protein extract

$\llbracket \Delta \mathrm{A} \rrbracket$ _240=A_Start-A_End

$\mathrm{df}=$ Dilution factor $(\mathrm{df}=50)$

$1000=$ convert $\mathrm{mM}$ to $\mu \mathrm{M}$

$2=$ volume of Cuvette $(2 \mathrm{~mL})$

$\mathrm{t}=$ Reaction time

$\varepsilon=$ Extinction coefficient of hydrogen peroxide $\left(40 \llbracket \mathrm{Mm} \rrbracket^{\wedge}(-1) \llbracket \mathrm{cm} \rrbracket^{\wedge}(-1)\right)$

\subsection{Statistical analysis}

Statistical analysis for all molecular and physiological data was performed using $\mathrm{R}$ version 3.5.3 [21] and RStudio version 1.1.463 [22]. Data were analyzed by ANOVA for a completely randomized design with treatments as fixed effects and replicate as random effect. Mean values were compared using Duncan test function provided in the agricolae package [23] at $5 \%$ significance level of probability.

\section{Results}

\subsection{Identification of candidate genes}

To compare the expression of identical genes (common genes) in the two genotypes, heat map analysis was used, in which red color indicated up-regulate and blue color indicated down-regulated genes (Fig1). According to Fig 1, heatmap clustering refers to the task of grouping together a set of samples based on the similarity of their gene expression patterns, and as much as gene expression is different, they fall into more distant clusters (Fig1). 


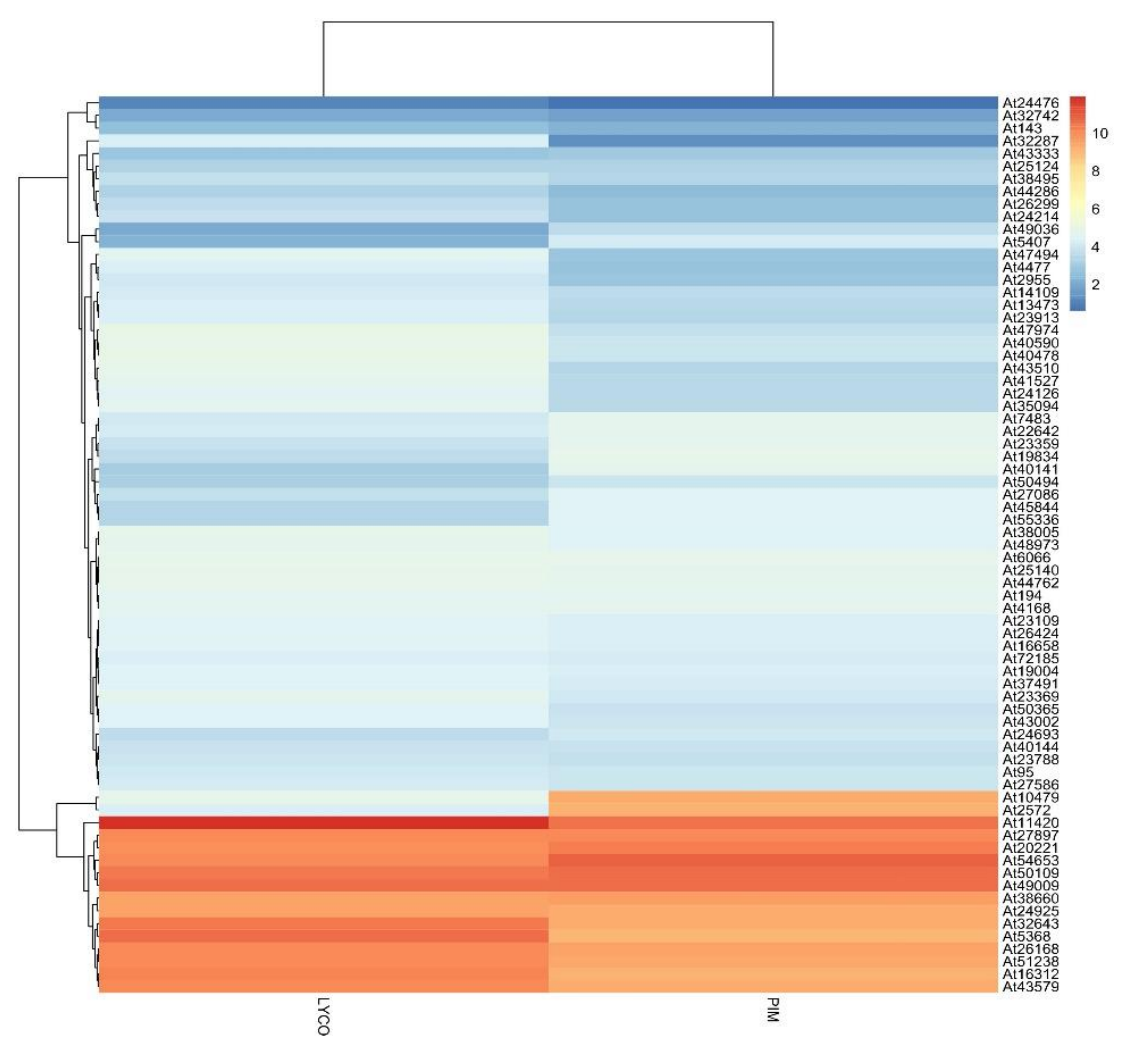

Figure 1. Heat map for identical genes in two genotypes of sensitive and tolerant with expression values as $\operatorname{LogFC}+7$ (To have positive values, seven were added to all values). Red color represents up-regulate genes and the blue color represents down-regulate genes.

Stress-responsive genes were identified using functional analysis. In sensitive genotype, up- and down-regulated genes had $13.88 \%$ and $25 \%$ of stress response genes, respectively, whereas in tolerant genotype, up- and down-regulated genes were $18.91 \%$ and $19.60 \%$, respectively. It is clear that in the tolerant genotype, stress-related genes are more active. As shown in Figure2, 27.7\% of the down-regulated genes were common between sensitive and tolerant genotypes, whereas only $6.4 \%$ of the up-regulated genes were common between the two genotypes. Interestingly, one gene showed increased expression in the tolerant genotype and decreased expression in the sensitive genotype, whose unigene code was at.2572 (Fig2). 


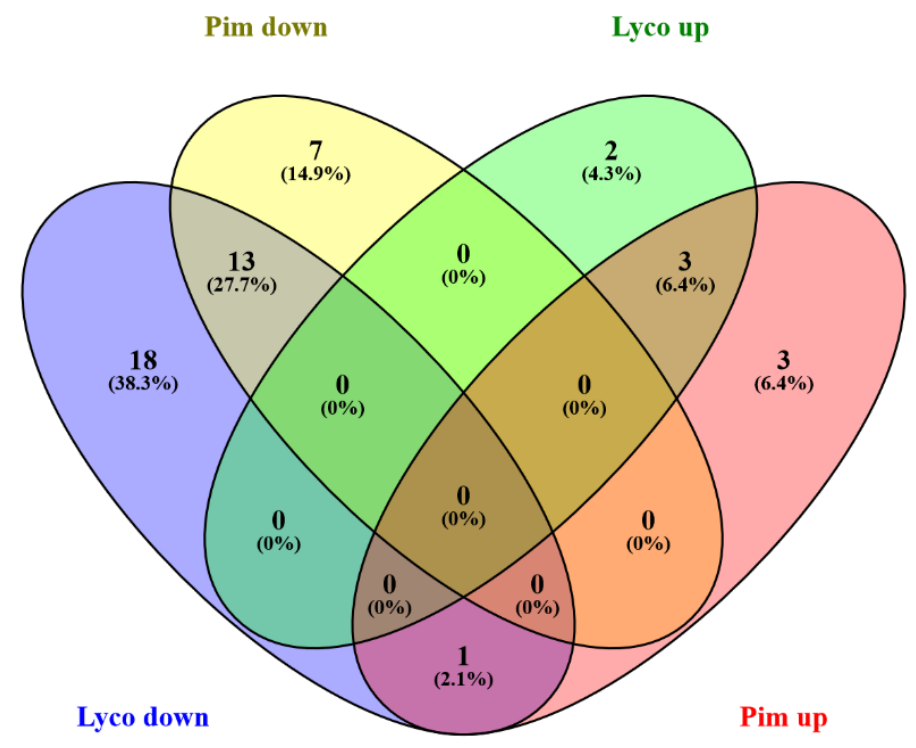

Figure 2. Comparing list of up- and down regulate genes in sensitive and tolerant tomato genotypes.

According to the Fig3, in drought stress conditions, FBA2, CEL2, HSP21, CAB3, ASN3, GAD5, HSA32, SSP5, etc. genes in sensitive genotype and HSP21, HSA32, PSY, ACS9, SAMDC, GAD5, SGB1, ABCF1, IAA19, FBA2, SMC2, etc. genes in tolerant genotype showed increased expression, while DOX1, EXLB1, XTR6, OSM34, LAC7, LRX1, PPC3, ICL, RHS19, LAC7, APR1, XTH26, SKU5, ETR2, RTE1, ERF1, EFE, VND7, etc. genes in sensitive cultivar and HRGP1, RHS19, FLS5, LAC7, DOX1, FRU, ICL, PPC3, CHI, EFE, XTH7, PUP4, ARP4, CBSX3, XTH25, PME3, XPL1, SMO2, etc. genes decreased in tolerant cultivar. STRING only retains associations between direct pathway members or within protein complexes with a high, uniform score (0.900), and to find the hub genes with a high degree of connectivity, we have to draw a gene network for these proteins. 

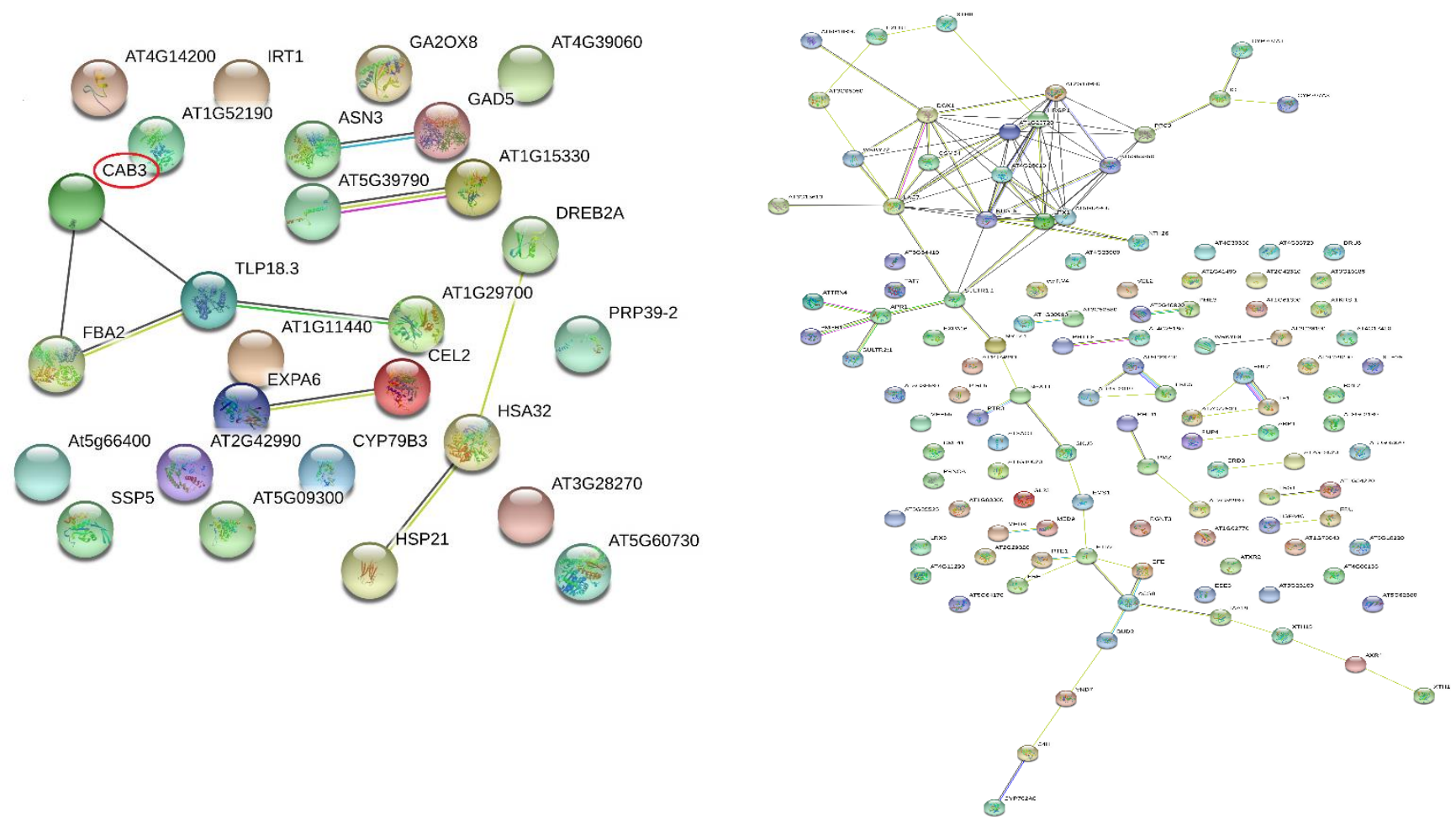

(a)

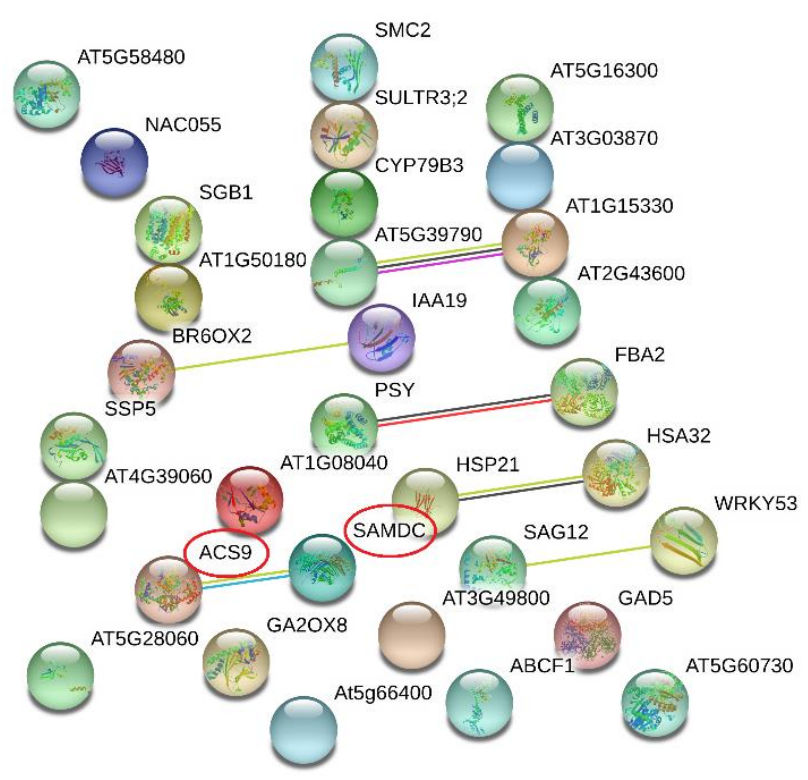

(b)

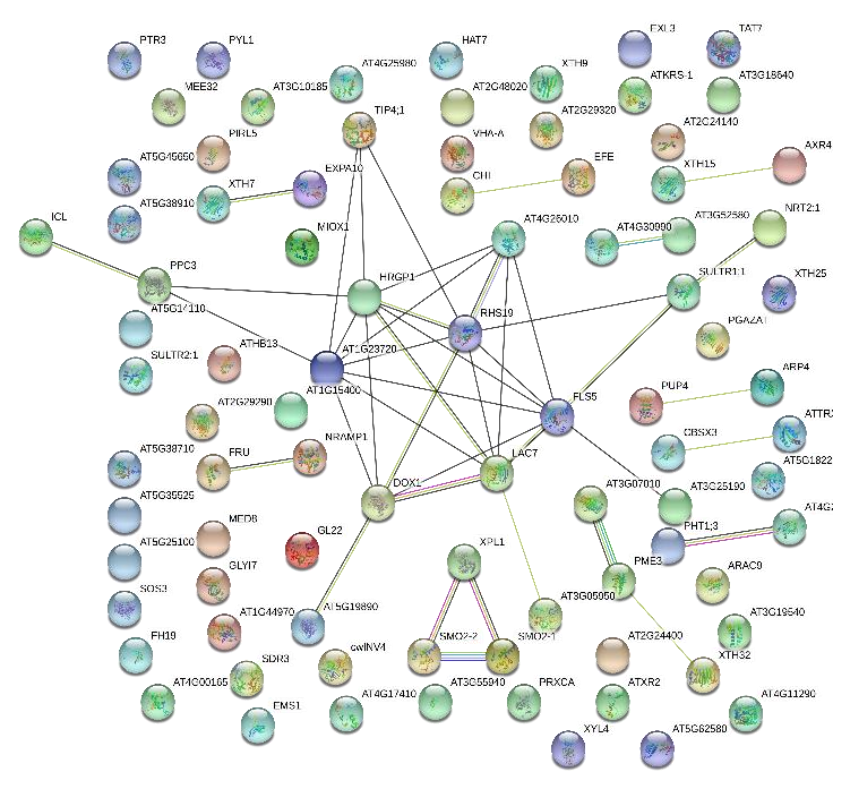

(c)

(d)

Figure 3. Protein interaction of two sensitive and tolerant tomato genotypes with increased and decreased expression. (a) Up-regulate genes in Solanum lycopersicum. (b) Down-regulate genes in Solanum lycopersicum. (c) Up-regulate genes in Solanum pimpinellifolium. (d) Down-regulate genes in Solanum pimpinellifolium. In these interactions, each node indicates a protein and the connecting lines of the nodes demonstrate the interaction between those proteins. The color of the connecting lines (strings) in figure 2 represents: Known interactions from curated databases and experimentally determined interactions are denoted by blue and purple strings, interactions based on gene neighborhood, gene fusions and gene co-occurrence are indicated by green, red and dark blue strings while interactions on the text mining, co-expression and protein homology shown by yellow, black and dark purple strings, respectively. 
We plotted a gene network based on a CytoHubba plugin (Fig4). CytoHubba was employed to explore PPI network hub genes; it provides a user-friendly interface to explore important nodes in biological networks and calculates using eleven methods, which we used here three algorithms of Closeness, Degree, and MNC [24].
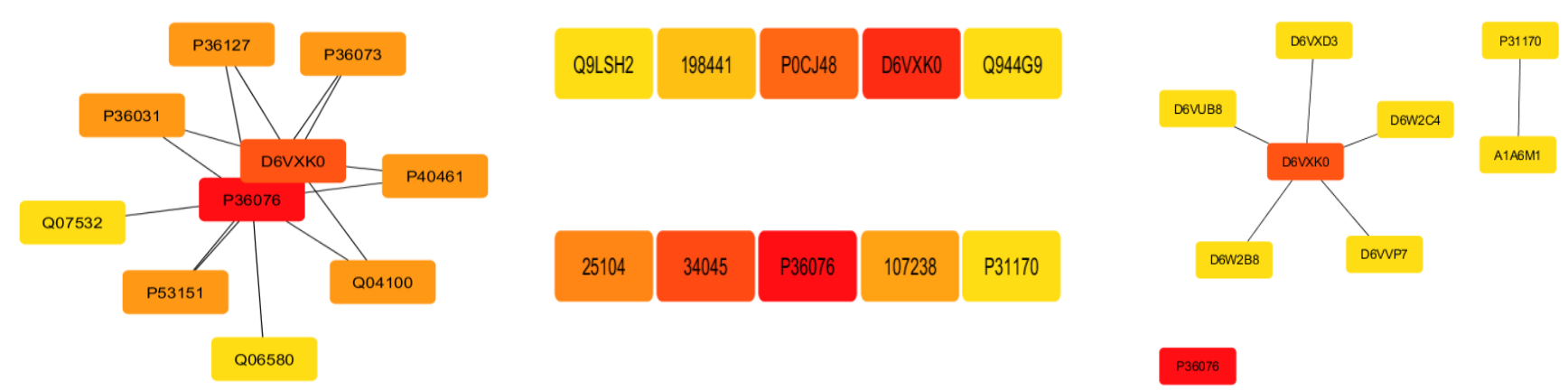

Closeness

Degree

MNC

(a)
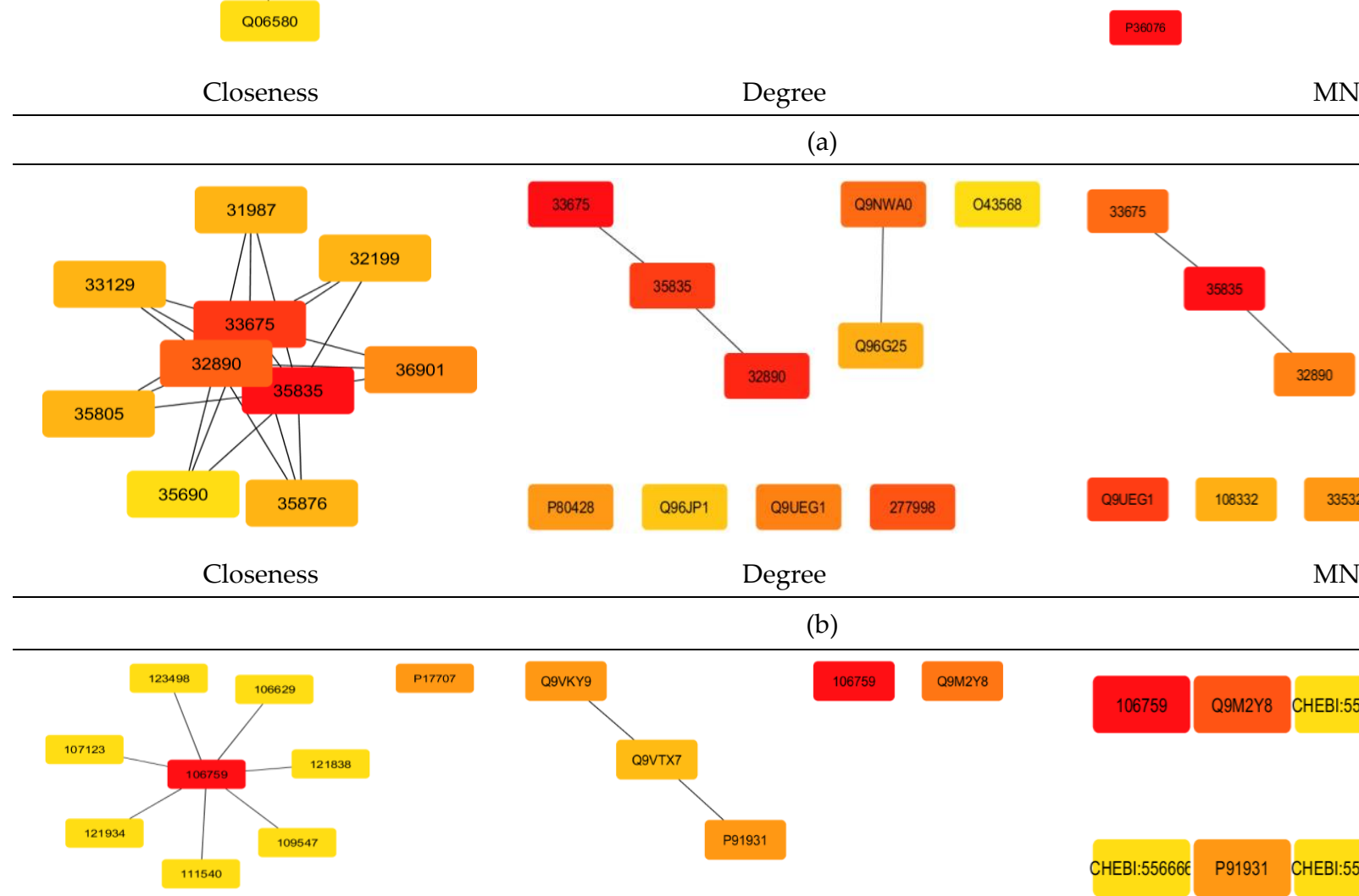

\section{(c)}
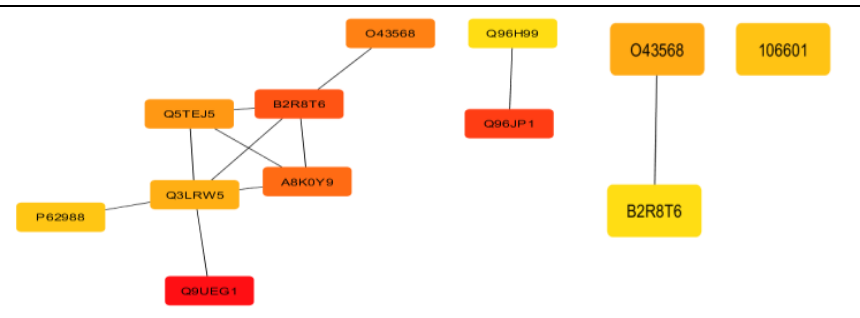

Q965P1 108332 QQUEG1

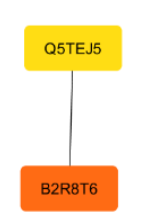


(d)

Figure 4. Gene networks of two tomato genotypes based on three algorithms of CytoHubba plugins. (a) Solanum lycopersicum \& Up-regulate genes (b) Solanum lycopersicum \& Down-regulate genes (c) Solanum pimpinellifolium \& Up-regulate genes. (d) Solanum pimpinellifolium \& Down-regulate genes.

The genes that were most common in the three algorithms were selected and listed in Table 3. In this study, three genes that were overexpressed in two tomato species were selected and analyzed. Selected genes in Solanum lycopersicum include CAB3, and in Solanum pimpinellifolium include SAMDC and ACS9.

Table3. Most common genes in three algorithms of CytoHubba plugin

\begin{tabular}{|c|c|c|}
\hline $\begin{array}{c}\text { Uniprot } \\
\text { accession }\end{array}$ & Gene Name & Gene Function \\
\hline \multicolumn{3}{|r|}{ Solanum lycopersicum \& Up-regulate } \\
\hline P36076 & CAB3 & Coenzyme A biosynthesis protein 3 \\
\hline D6VXK0 & CAB3 & Chlorophyll a-b binding protein 2 , chloroplastic \\
\hline 34045 & CAB3 & Chlorophyll a-b binding protein 2 , chloroplastic \\
\hline P0CJ48 & LHCB1.1, CAB3 & Chlorophyll $\mathrm{a}-\mathrm{b}$ binding protein 2 , chloroplastic \\
\hline \multicolumn{3}{|r|}{ Solanum lycopersicum \& Down-regulate } \\
\hline 33675 & ARP4 & $\begin{array}{l}\text { Nuclear actin-related protein involved in chromatin remodeling; com- } \\
\text { ponent of chromatin-remodeling enzyme complexes }\end{array}$ \\
\hline 32890 & MED8 & $\begin{array}{c}\text { Subunit of the RNA polymerase II mediator complex; associates with } \\
\text { core polymerase subunits to form the RNA polymerase II holoenzyme; } \\
\text { essential for transcriptional regulation }\end{array}$ \\
\hline 35835 & CSE2 & Mediator of RNA polymerase II transcription subunit 9 \\
\hline \multicolumn{3}{|r|}{ Solanum pimpinellifolium \& Up-regulate } \\
\hline 106759 & AMD1 & adenosylmethionine decarboxylase 1 \\
\hline Q96286 & SAMDC1 & S-adenosylmethionine decarboxylase proenzyme 1 \\
\hline Q9M2Y8 & ACS9 & 1-aminocyclopropane-1-carboxylate synthase 9 \\
\hline \multicolumn{3}{|c|}{ Solanum pimpinellifolium \& Down-regulate } \\
\hline 33675 & ARP4 & $\begin{array}{l}\text { Nuclear actin-related protein involved in chromatin remodeling; com- } \\
\text { ponent of chromatin-remodeling enzyme complexes }\end{array}$ \\
\hline Q9UEG1 & UBC & Ubiquitin C \\
\hline Q96JP1 & SLX4 & Structure-specific endonuclease subunit SLX4 \\
\hline B2R8T6 & RAD51A & DNA repair protein RAD51 homolog 1 \\
\hline 277998 & $\operatorname{arp} 42$ & $\begin{array}{l}\text { SWI/SNF and RSC complexes subunit arp42 (Actin-related protein 42) } \\
\text { (Chromatin structure-remodeling complex subunit arp42) }\end{array}$ \\
\hline 11778 & GRF1 & general regulatory factor 1 \\
\hline
\end{tabular}


CAB3 protein acts on the photosynthetic pathway in chloroplasts and plays a role in receiving light and transmitting energy to the plant. SAMDC protein is involved in two metabolic pathways including, cysteine-methionine and arginine-proline. In both pathways, this enzyme (S-adenosylmethionine decarboxylase) catalyzes S-adenosyl-L-methionine to the S-adenosylmethionine amine. ACS9 protein is also involved in the cysteinemethionine metabolism pathway. This enzyme catalyzes the conversion of S-adenosyl-Lmethionine to 1-aminocyclopropane-1-carboxylate (ACC). The location of protein activity and placement in CAB3, SAMDC, and ACS9 were predicted in chlorophyll, cytoplasm, and nucleus, respectively. According to the Genevestigator analysis (Fig5), expression levels of genes CAB3 and SAMDC were varied at different stages of development, but at ACS9, it is almost constant. Gene expression of SAMDC increased at vegetative and flowering stages but decreased at the fruiting stage, while, CAB3 was highest at the vegetative stage and decreased at the flowering stage, and it increased again at the fruiting stage and decreased at the fruit ripening stage (Fig5a). 

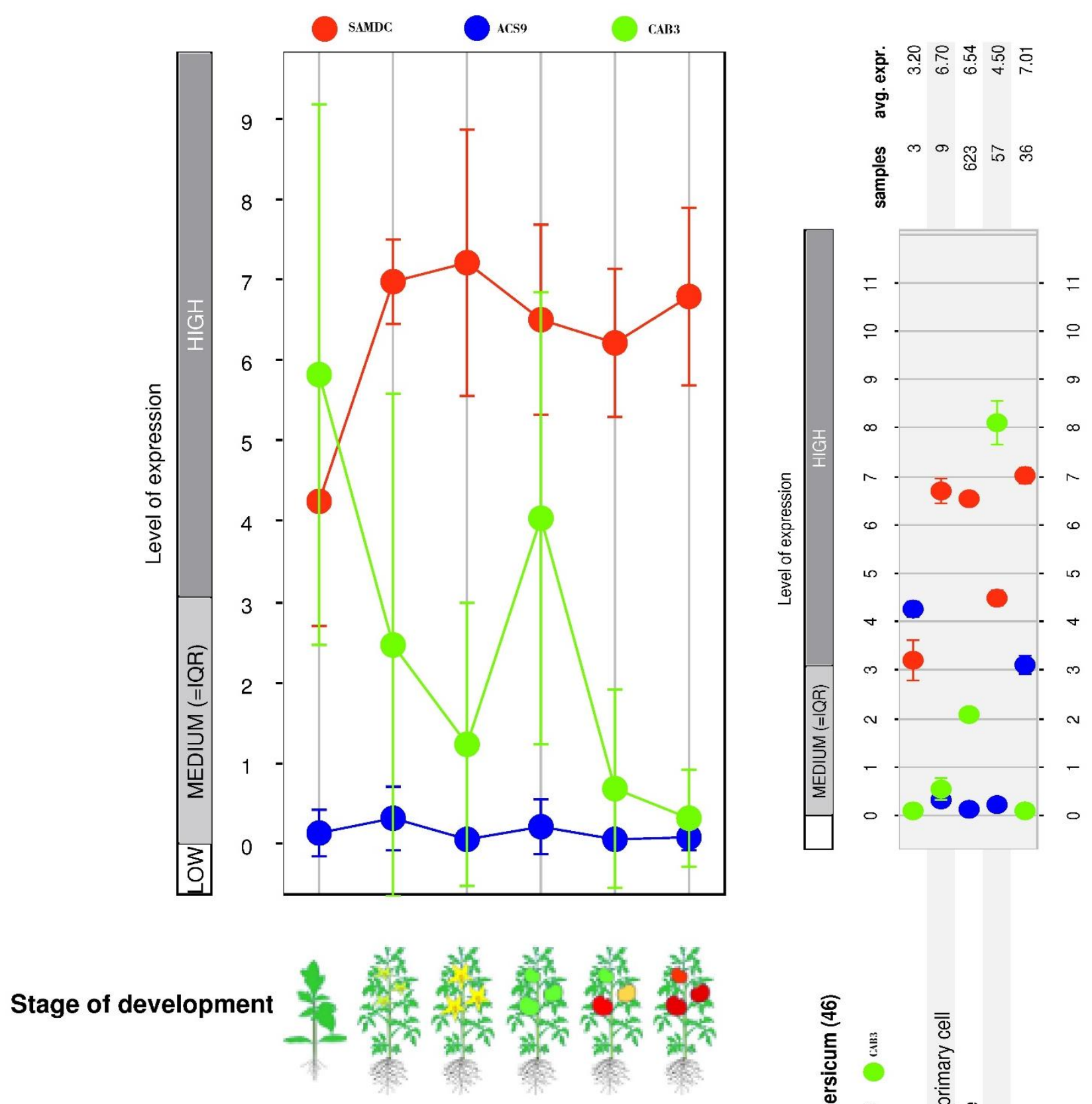

\section{Number of samples}

$\begin{array}{llllll}33 & 8 & 27 & 252 & 227 & 74\end{array}$

(a)

(b)

Figure 5. Expression level of candidate genes in different tissues and developmental stages using Genevestigator software.

The highest expression levels of CAB3, SAMDC, and ACS9 genes were observed in shoots, roots, and callus, respectively (Fig $5 b)$. The instability index, hydrophobicity percentage, and isoelectric point of each gene are given in Table 4. S-adenosylmethionine decarboxylase (SAMDC) plays a role in the polyamines (PAs) pathway and the biosynthesis of spermidine I, II, III, while, 1-aminocyclopropane-1-carboxylate synthase 9 (ACS9) involved in ethylene biosynthesis and L-methionine salvages cycle. 
Table4. Physicochemical properties of candidate proteins using Protparam server.

\begin{tabular}{ccccc}
\hline Protein & $\begin{array}{c}\text { Instability index } \\
\text { (II) }\end{array}$ & $\begin{array}{c}\text { Grand average of hydropathicity } \\
\text { (GRAVY) }\end{array}$ & $\begin{array}{c}\text { Theoretical } \\
\text { pI }\end{array}$ & G+C \\
\hline CAB3 & 43.67 (unstable) & 0.654 & 5.06 & 47.17 \\
SAMD1 & 43.45 (unstable) & 0.691 & 4.96 & 41.76 \\
ACS9 & 45.21 (unstable) & 0.820 & 5.01 & 40.84 \\
\hline
\end{tabular}

\subsection{Gene expression analysis}

Results of gene expression analysis showed that the CAB3 gene in both sensitive and tolerant tomato genotypes did not a significant difference compared to the control, but the SAMDC gene decreased in both genotypes and the ACS9 gene decreased in sensitive genotype and increased in tolerant genotype. A comparison of gene expression in sensitive and tolerant genotypes showed that expression levels of all three genes in tolerant genotype were more than sensitive. The expression of CAB3 and SAMDC genes in tolerant genotypes was 2.26 and 2.42 times more than that of sensitive genotype, whereas ACS9 gene expression in tolerant genotype was 413.23 times more than sensitive genotype. The amount of ACS9 gene expression is significant to the sensitive genotype since this gene controls ethylene production, therefore appears to play a key role in drought condition tolerance (Fig6).

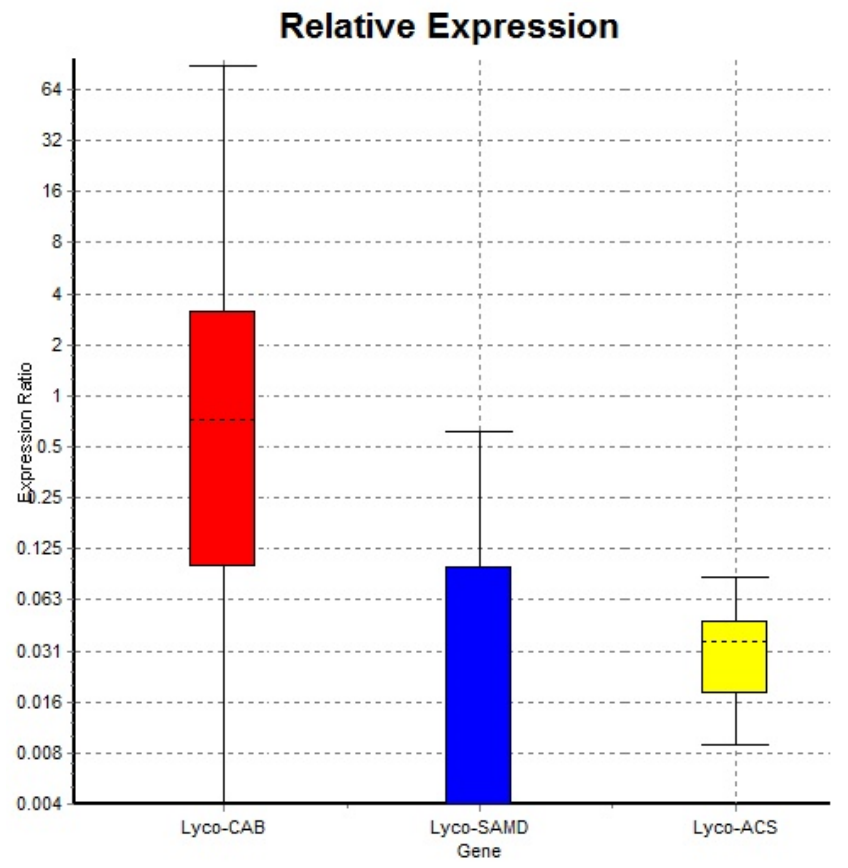

(a)

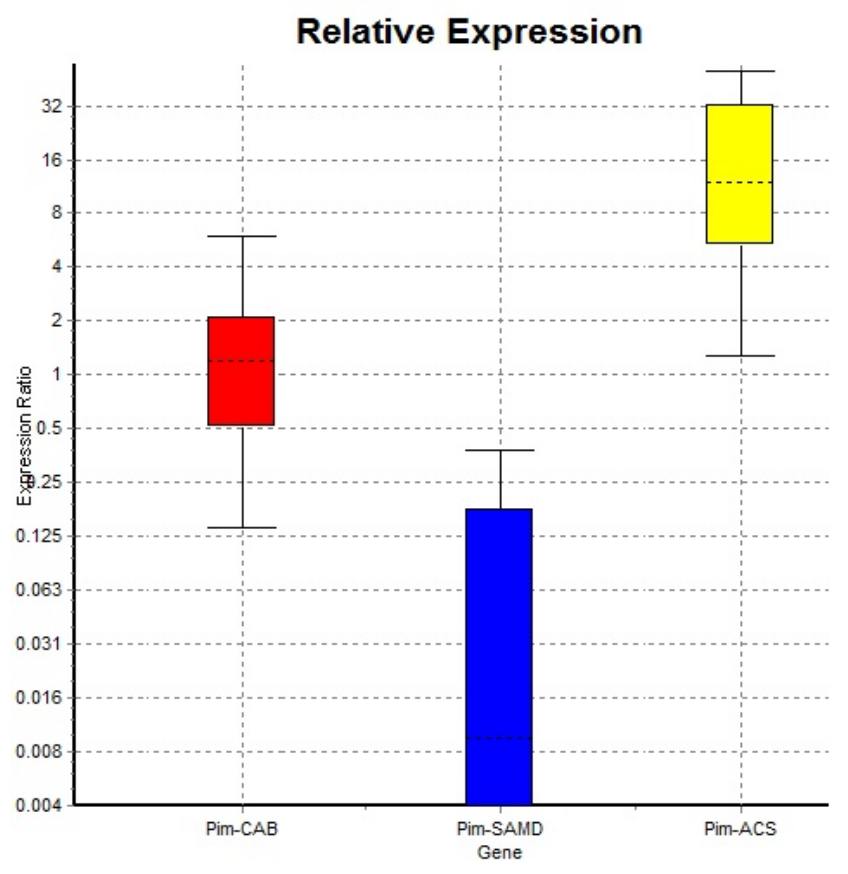

(b)

Figure 6. Expression ratio of three genes in tolerant and sensitive genotypes of tomato (a) Relative expression of Solanum lycopersicum. (b) Relative expression of Solanum pimpinellifolium. 
The ANOVA analysis of physiological parameters in tomato genotypes grew under drought stress indicated that the single effects of Genotype and Treatment, also their interactions were highly significant $(\mathrm{P}<0.01)$ in Chlorophyll a and $\mathrm{b}$, Proline, MDA, CAT, and APX (Table 5).

Table.5 ANOVA analysis of some physiological parameters in tomato genotypes under drought stress

\begin{tabular}{|c|c|c|c|c|c|c|c|}
\hline $\begin{array}{l}\text { Sources } \\
\text { of Variation }\end{array}$ & $\mathrm{df}$ & Chla & Chlb & $\begin{array}{l}\text { Pro- } \\
\text { line }\end{array}$ & MDA & CAT & APX \\
\hline Genotype (G) & 1 & $0.001^{*}$ & $0.0008^{*}$ & $2.76^{* *}$ & $1.32^{* *}$ & $2084^{* *}$ & $191 * *$ \\
\hline Treatment $(\mathrm{T})$ & 1 & $0.002^{* *}$ & $0.0023^{* *}$ & $6.69^{* *}$ & $12.8^{* *}$ & $6800^{* *}$ & $1176^{* *}$ \\
\hline $\mathrm{G} \times \mathrm{T}$ & 1 & $0.002^{* *}$ & $0.0064^{* *}$ & $0.13^{* *}$ & $1.21^{* *}$ & $1694^{* *}$ & $963^{* *}$ \\
\hline Error & 6 & 0.001 & 0.002 & 0.003 & 0.035 & 34 & 5 \\
\hline
\end{tabular}

\subsubsection{Chlorophyll a and $\mathrm{b}$}

Under drought conditions, chlorophyll a content in the tolerant genotype decreased by $5 \%$ compared to the control, while in the sensitive genotype it was $15 \%$. Chlorophyll a in the tolerant genotype was more than the sensitive genotype. The difference in chlorophyll a content in tolerant to sensitive plants was 0.007 in control samples and 0.015 $\mathrm{mg} / \mathrm{g}-1 \mathrm{FW}$ in treated samples, respectively (Fig7a). Similarly, chlorophyll b decreased by $6 \%$ and $11 \%$ in tolerant and sensitive genotypes, respectively. Also, chlorophyll b content in the tolerant genotype was 0.0014 (in control) and $0.0021 \mathrm{mg} / \mathrm{g}-1 \mathrm{FW}$ (in treated samples) higher than the sensitive genotype. According to the above results, the tolerant genotype had a higher ability to retain chlorophyll $a$ and $b$ than the sensitive genotype (Fig7b).

\subsubsection{Proline}

Under dehydration conditions, for osmotic regulation, the proline content of plants increases to prevent cell plasmolysis. In our experiment, under drought stress, proline content increased in both tolerant and sensitive genotypes. Proline content in tolerant to sensitive genotypes increased by $4 \%$ and $5 \%$ in control and treated samples, respectively (Fig7c).

\subsubsection{Malondialdehyde (MDA)}

Water stress induces lipid peroxidation and MDA accumulation in plants. In both genotypes, MDA increased significantly under stress conditions. Lipid peroxidation in sensitive and tolerant genotypes was 5.35 and 3.42 times higher than control, respectively (Fig8d).

\subsubsection{Catalase enzyme (CAT)}

CAT is essential for catalyzes of $\mathrm{H} 2 \mathrm{O} 2$ into water and oxygen, so, increasing this enzyme under stress conditions protects the plants. In our experiment, CAT activity had a significant increase in tolerant genotype under stress conditions. As shown in Figure 7e, the activity ratio of this enzyme in tolerant genotype was 2.41 times higher than sensitive genotype (Fig7e). 


\subsubsection{Ascorbate peroxidase (APX)}

APX activity was increased by water deficit. According to the results, the highest APX activity was recorded in tolerant genotype under drought condition $(215.84 \mathrm{U} / \mathrm{ml})$, and the lowest was obtained in the control treatment in sensitive genotype $(127.95 \mathrm{U} / \mathrm{ml})$ (Fig7f).

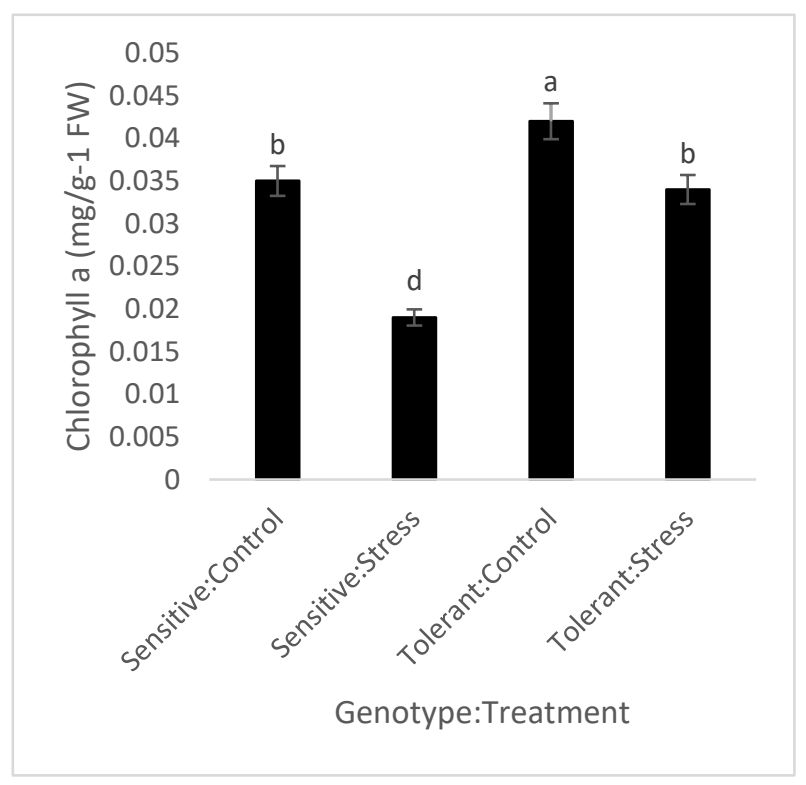

(a)

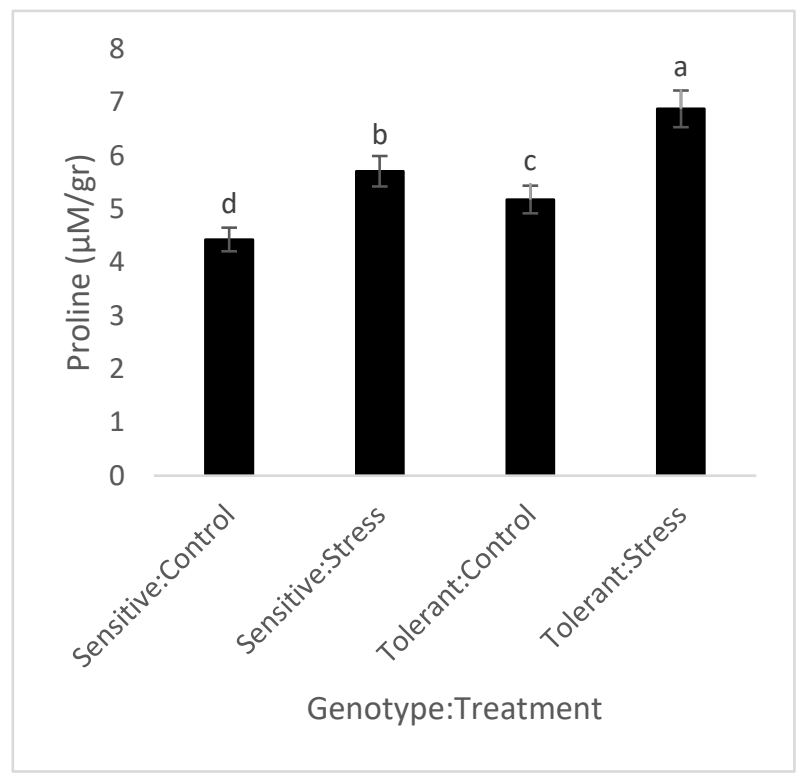

(c)

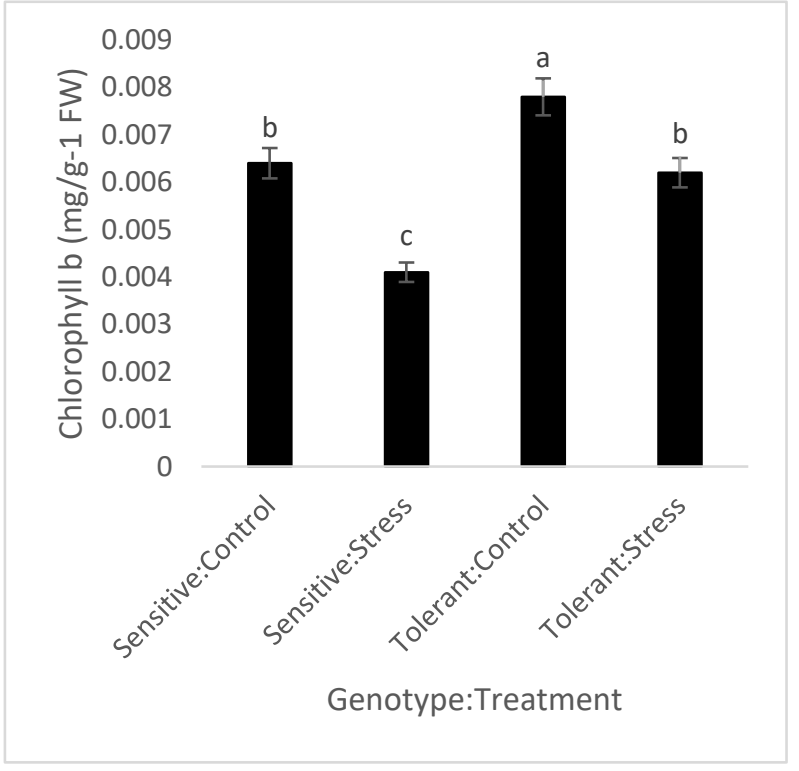

(b)

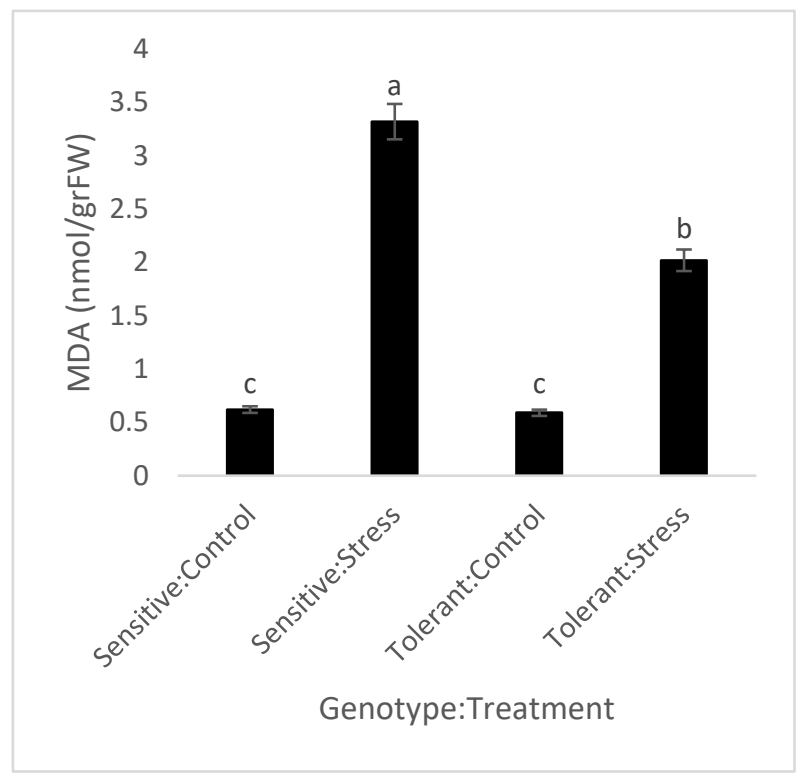

(d) 


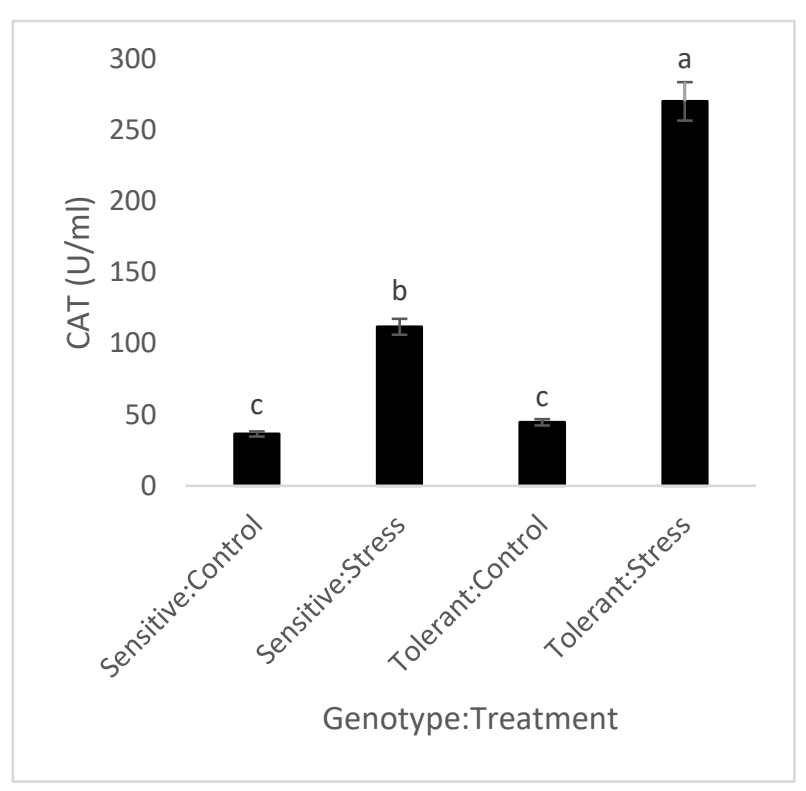

(e)

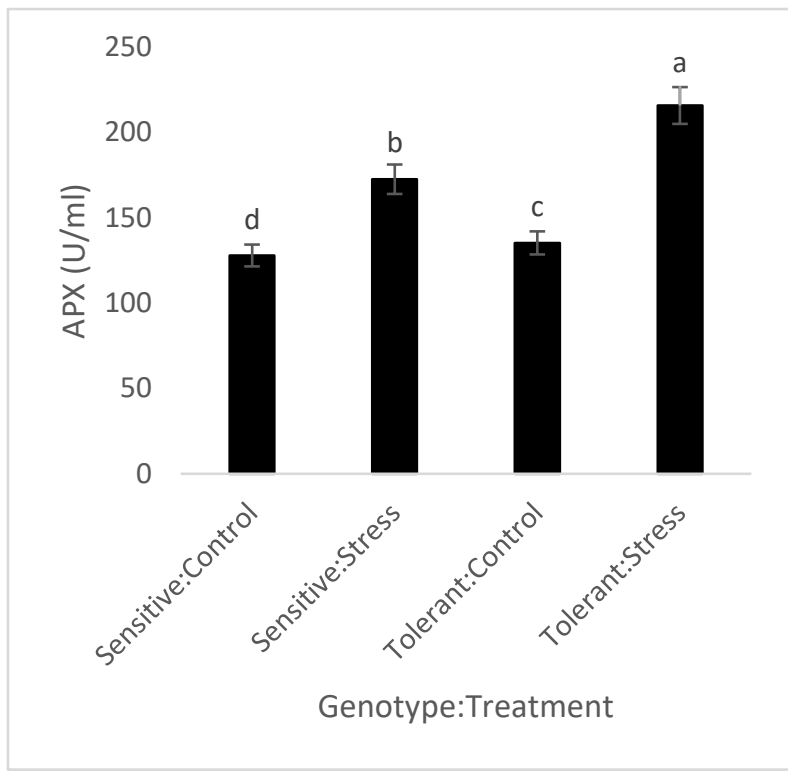

(f)

Figure 7. Interaction of genotypes and drought stress levels on some traits of tomato.

\section{Discussion}

Water shortage represents a major global abiotic stress that limits plant production by inhibition of plant growth and development [25]. Drought induces ROS overproduction and leads to the disruption of membrane integrity and osmotic balance in plant cells. The result of these changes is a decrease in crop quality and quantity, which causes crop yield losses [26]. Therefore, it is important to identify the differentially expressed genes (DEGs) under drought stress condition and their expression evaluation, as well as to examine the physiological parameters affected by stress, including the photosynthetic system, osmolytes (proline), MDA, and antioxidant enzymes (CAT and APX). In this study, three genes CAB3 (LHCB), SAMDC, and ACS9 that up-regulated under drought stress conditions were selected and examined.

Regulation of LHCB expression is raised as one of the important plant mechanisms to modulate chloroplast functions [27]. Previous reports showed that the members of the LHCB family play an important role in plant adaptation to environmental stresses [28], as well as their expression is regulated by ABA [29]. The plants most affected by drought stress (sensitive plants) produce higher ABA levels, thereby increasing the expression of the LHCB gene. LHCB genes involved in Saccharum narenga leaves in response to water deficit [30]. In cotton leaves, chlorophyll a/b-binding genes, which involved in the lightharvesting complex of photosystem II (PSII) was significantly down-regulated by waterlogging stress [31]. Xu et al. [32] reported that down-regulation or disruption of any member of the LHCB family reduces the responsiveness of stomatal movement to ABA, and therefore results in a decrease in plant tolerance to drought stress in Arabidopsis thaliana. In contrast, our results showed that the expression of LHCB in both sensitive and tolerant cultivars of tomato was not significantly different from control, which could be due to different conditions such as stress duration, plant type, environment temperature, culture medium, and so on.

Another up-regulate gene, SAMDC, is the key enzyme for the biosynthesis of polyamines (PAs). Prior studies reported that PAs were involved in plant reactions to abiotic stresses such as cold, drought, and salinity [33]. SAMDC protein is involved in two metabolic pathways: In the cysteine-methionine metabolism pathway, in the absence of this 
enzyme, S-adenosyl-L-methionine is converted to ethylene and homocysteine [34]. This enzyme inhibits ethylene production and aging in the plant [35], therefore, the plants are less affected by adverse environmental conditions. In the arginine-proline metabolism pathway, this enzyme results in the production of both spermine and spermidine. These compounds in plants embrace a wide range of biological processes, such as cell division, growth, differentiation, aging, somatic embryogenesis, root and shoot formation, pollen development, flowering, fruit maturation, and response to environmental stress [36]. Marco et al. [37] indicated that overexpression of the SAMDC1 gene in Arabidopsis produces Spm accumulation and leads to plants with improved tolerance to salt stress. Results of Pál et al. [38] showed that there is a positive feedback loop between ABA and PAs. Overexpression of the genes of PA synthesis enzymes, such as SAMDC, resulted in increased ABA biosynthesis and ABA plays a central role in the improvement of plant drought resistance [39]. In our experiment, the expression of this gene was decreased in both sensitive and tolerant cultivars, perhaps one of the reasons that tomato is sensitive to drought conditions is to decrease the expression of this gene.

Finally, the last gene to be studied is ACS9. This enzyme eventually results in the production of ethylene and 2-exobutanate [40]. Developmental steps, stress conditions, and the presence of phytohormones (such as auxin and ethylene itself) are the principal inducers of transcriptional variations in ACS genes [41]. RT-PCR analysis revealed that abiotic stressors induce the expression of the wild-type ACS gene which is involved in ACC production. Under stressful conditions, plants can produce high levels of ACC that subsequently increase ethylene concentrations and leading to an inhibition of plant growth and development $[42,43]$. Ethylene regulates a defense response, mostly in fullgrown leaves, and growth response in young leaves [44]. Nascimento et al. [40] report that ACC itself, independently of ethylene, may play a role as a signaling molecule that controls plant growth and development. It is interesting that ACC conjugates with other phytohormones such as jasmonic acid, which is closely linked to plant defense [45], so suggests a role for ACC in phytohormone crosstalk and a possible effect in mediating some plant defense responses. Similar to the results of Eun et al. [43], in our results, the expression of ACS was increased in wild cultivar (tolerant) but decreased in the sensitive cultivar.

Our three proteins have a positive index, so they are stable at high temperatures. The instability index could be used as an indirect degree of the in vivo half-life of a protein [46]. Proteins with a stability index of more than 40, have an in vivo half-life of fewer than 5 hours, whilst, the proteins with a stability index of less than 40 , have an in vivo half-life of more than 16 hours [47]. According to Table 4, the stability index of our proteins is greater than 40, and therefore, they are unstable and their half-life is less than 5 hours. GRAVY index displays the solubility of the proteins, in which positive GRAVY is hydrophobic and negative GRAVY is hydrophilic proteins. The GRAVY index of our three proteins is positive, so they are among the hydrophobic proteins that are a current property in the membranous proteins [48]. The hydrophobic character of these genes is correlated with genes related to different stresses, such as the LEA [49], heat shock protein chaperones, which do binds with non-native proteins and thus inhibit their aggregation during abiotic stress conditions [50].

Dehydration leads to the induction of signal transduction cascade and ultimately activation of transcription factors, which each activates a set of target genes, including those necessary for the synthesis of protective molecules and amplification of the plant defense system [51]. Photosynthetic pigments allow plants to attract energy from light, therefore foliar Chlorophyll content is a key factor affecting the performance of plant photosynthesis [52]. In our experiment, dehydration led to a significant reduction in Chlorophyll levels in tomatoes, especially in sensitive genotypes. Several types of research also have explained that water stress significantly reduces the Chlorophyll a and b of various crops $[53,54]$. The decrease in Chlorophyll content under drought stress might be due to reduction in the synthesis of the principal Chlorophyll pigment complexes encoded by the CAB 
gene family, or to the demolition of the pigment-protein complexes that protect the photosynthetic system, or to oxidative damage of chloroplast lipids and proteins [55].

Proline protects plants from stress by contributing to cellular osmotic adjustment, ROS detoxification, protection of membrane integrity, and enzymes/protein stabilization [56]. Therefore, the accumulation of proline increases the tolerance of plants under stress conditions. Our results also indicated the accumulation of proline under stress conditions. The tolerant genotype had a higher proline content than sensitive, indicating that it is more tolerant. MDA is a product of peroxidation of unsaturated fatty acids in phospholipids, and the lipid peroxidation level is used as an indicator of free radical damage to cell membranes under stress [57]. Under stress conditions, MDA content increased in both tomato genotypes, which is significant in sensitive genotype. Many antioxidants play a pivotal role in hindering the oxidative damage caused by unfavorable conditions, two of which are CAT and APX. CAT activity in response to drought stress suggests a prominent role for this enzyme in the protection of leaf tissue against oxidative damage. APX also acts as the key enzyme to catalyze the reaction of $\mathrm{H} 2 \mathrm{O} 2$ into $\mathrm{H} 2 \mathrm{O}$ [58]. The expression of APX may be activated by various factors, including water deficit [59]. In our experiment, both antioxidant enzymes were increased under stress conditions. The ratio of enzyme activity in tolerant to sensitive genotypes was higher in CAT enzyme than APX.

\section{Conclusions}

Tomato is a sensitive plant to drought conditions and so far, many methods have been developed to prevent crop reduction. Since genes in each organism play a decisive role in any situation, so we were looking for a way to identify stress-tolerant genes. In this study, after the transcriptome analysis, we found three key genes, which include CAB3, SAMDC, and ACS9. The results of our analysis showed that these three genes play an important role in stress tolerance. CAB3 genes lead to the synthesis of chlorophyll pigment complexes and reduced expression leads to a decrease in chlorophyll content. SAMDC gene is involved in the biosynthesis of polyamines. Polyamines have anti-senescence and anti-stress effects, antioxidant properties as well as membrane and cell wall stability. Therefore, the decrease in its expression led to a decrease in antioxidant enzymes and an increase in lipid peroxidation in sensitive to tolerant genotype. The ACS9 gene is involved in the ACC production and subsequently in the production of ethylene. Under stress, ACS9 inhibits plant growth, and ACC itself, independent of ethylene, acts as a signaling molecule and controls plant growth. ACS9 gene was significantly increased in tolerant genotype compared to sensitive cultivar. According to this result, the tolerant plant avoids drought and through ethylene production, it led to the closure of stomatal pores, reduced water loss, and reduced membrane damage. This method is one of the most basic defense systems in tolerant plants.

Author Contributions: “Conceptualization, Rahele Ghanbari Moheb Seraj and Masoud Tohidfar; methodology, X.X.Rahele Ghanbari Moheb Seraj; software, Rahele Ghanbari Moheb Seraj; validation, Rahele Ghanbari Moheb Seraj, Masoud Tohidfar and Asadollah Ahmadikhah; formal analysis, Rahele Ghanbari Moheb Seraj; investigation, Masoud Tohidfar; writ-ingoriginal draft preparation, Rahele Ghanbari Moheb Seraj; writing - review and editing, Masoud Tohidfar; visualization, Asadollah Ahmadikhah.Funding: Please add: "This research received no external funding" or "This research was funded by NAME OF FUNDER, grant number XXX" and "The APC was funded by $X X X$ ". Check carefully that the details given are accurate and use the standard spelling of funding agency names at https://search.crossref.org/funding. Any errors may affect your future funding.

Conflicts of Interest: “The authors declare no conflict of interest."

\section{References}

1. Zalibekov, ZG. The arid regions of the world and their dynamics in conditions of modern climatic warming. Arid Ecosyst 2011, 1, 1-7. https://doi.org/10.1134/S2079096111010094

2. Song, W; Zhao, H; Zhang, X; Lei, L; Lai, J. Genome-wide identification of VQ motif-containing proteins and their expression profiles under abiotic stresses in maize. Front Plant Sci 2016, 6, 1177. https://doi.org/10.3389/fpls.2015.01177 
3. Singh, B; Kukreja, S; Goutam, U. Milestones achieved in response to drought stress through reverse genetic approaches. F1000Res 2018, 7, 1311. https://doi.org/10.12688/f1000research.15606.1

4. Zhang, X; Lei, L; Lai, J; Zhao, H; Song, W. Effects of drought stress and water recovery on physiological responses and gene expression in maize seedlings. BMC Plant Biol 2018, 18(1), 68. https://doi.org/10.1186/s12870-018-1281-x

5. Mahmud, AA; Hossain, M; Kadian, MS; Hoque, MA. Physiological and biochemical changes in potato under water stress condition. Ind J Plant Physiol 2015, 20, 297-303. https://doi.org/10.1007/s40502-015-0173-4

6. Sade, B; Soylu, S; Yetim, E. Drought and oxidative stress. Afr J Biotechnol 2011, 10, 11102-11109. https://doi.org/10.5897/AJB11.1564

7. Zhou, R; Yu, X; Zhao, T; Ottosen, C; Rosenqvist, E; Wu, ZW. Physiological analysis and transcriptome sequencing reveal the effects of combined cold and drought on tomato leaf. BMC Plant Biol 2019, 19(1), 377. https://doi.org/10.1186/s12870-019-1982-9

8. Cuartero, J; Fernández-Muñoz, R. Tomato and salinity. Scientia Horticulturae 1998, 78(1-4), 83-125. https://doi.org/10.1016/S03044238 (98)00191-5.

9. Wudiri, BB; Henderson, DW. Effects of water stress on flowering and fruit set in processing-tomatoes. Sci Hortic 1985, 27(3-4), 189-198. https://doi.org/10.1016/0304-4238

10. Khan, N; Kazmi, RH; Willems, LAJ; van Heusden, AW; Ligterink, W; Hilhorst, HWM. Exploring the natural variation for seedling traits and their link with seed dimensions in tomato. PloS One 2012, 7 (8), e43991. https://doi.org/10.1371/journal.pone.0043991

11. Zhou, R; Yu, X; Ottosen, CO; Rosenqvist, E; Zhao, L; Wang, Y; Yu, W; Zhao, T; Wu, Z. Drought stress had a predominant effect over heat stress on three tomato genotypes subjected to combined stress. BMC Plant Biol 2017, 17, 24. https://doi.org/10.1186/s12870-017-0974-x.

12. Livak, KJ; Schmittgen, TD. Analysis of relative gene expression data using real-time quantitative PCR and the 2(-Delta Delta C (T)) Method. Methods 2001, 25(4), 402-408. https://doi.org/10.1006/meth.2001.1262

13. Ruijter, JM; Ramakers, C; Hoogaars, WM; Karlen, Y; Bakker, O; van den Hoff, MJ; Moorman, AF. Amplification efficiency: linking baseline and bias in the analysis of quantitative PCR data. Nucleic Acids Res 2009, 37(6), e45. https://doi.org/10.1093/nar/gkp045

14. Pfaffl, MW; Horgan, GW; Dempfle, L. Relative expression software tool (REST) for group-wise comparison and statistical analysis of relative expression results in real-time PCR. Nucleic Acids Res 2002, 30(9), e36. https://doi.org/10.1093/nar/30.9.e36

15. Arnon, DI; Allen, MB; Whatley, FR. Photosynthesis by isolated chloroplasts. IV. General concept and comparison of three photochemical reactions. Biochim Biophys Acta 1956, 20, 449-461. https://doi.org/10.1016/0006-3002 (56)90339-0

16. Mackinney, G. Absorption of light by chlorophyll solutions. J. biol. Chem 1941, 140(2), 315-322.

17. Bates, L; Waldren, RP; Teare, ID. Rapid determination of free proline for water-stress studies. Plant Soil 1973, 39, $205-207$. https://doi.org/10.1007/BF00018060

18. Stewart, RR; Bewley, JD. Lipid peroxidation associated with accelerated aging of soybean axes. Plant Physiol 1980, 65, 245-248. https://doi.org/10.1104/pp.65.2.245

19. Nakano, Y; Asada, K. Hydrogen peroxide is scavenged by ascorbate-specific peroxidase in spinach chloroplasts. Plant Cell Physiol 1981, 22, 867-880 https://doi.org/10.1093/oxfordjournals.pcp.a076232

20. Bergmeyer, HU; Grasse, M; Walterh, E. In: H.U. Bergmeyer (ed.), Methods of enzymatic analysis. 3rd ed 1983, 2, 164.

21. R Core Team. R: R Foundation for Statistical Computing; Vienna, Austria 2019, 2014.

22. RStudio Team. RStudio: Integrated Development Environment for R. 2018.

23. De Mendiburu, F. Agricolae: statistical procedures for agricultural research. $R$ Package Version 2017, 1, 2-7.

24. Chin, $\mathrm{CH}$; Chen, $\mathrm{SH} ; \mathrm{Wu}, \mathrm{HH}$; Ho, CW; Ko, MT; Lin, CY. CytoHubba: identifying hub objects and sub-networks from complex interactome. BMC Syst Biol 2014, 8(4), S11. https://doi.org/10.1186/1752-0509-8-s4-s11.

25. Dudziak, K; Zapalska, M; Börner, A; Szczerba, H; Kowalczyk, K; Nowak, M. Analysis of wheat gene expression related to the oxidative stress response and signal transduction under short-term osmotic stress. Sci Rep 2019, 9(1), 2743. https://doi.org/10.1038/s41598-019-39154-w

26. Sharma, A; Wang, J; Xu, D; Tao, S; Chong, S; Yan, D; Li, Z; Yuan, H; Zheng, B. Melatonin regulates the functional components of photosynthesis, antioxidant system, gene expression, and metabolic pathways to induce drought resistance in grafted Carya cathayensis plants. Sci Total Environ 2020, 713, 136675. https://doi.org/10.1016/j.scitotenv.2020.136675

27. Thines, B; Harmon, FG. Four easy pieces: mechanisms underlying circadian regulation of growth and development. Curr Opin Plant Biol 2010, 14(1), 31-37. https://doi.org/10.1016/j.pbi.2010.09.009

28. Zhao, P; Cui, R; Xu, P; Wu, J; Mao, JL; Chen, Y; Zhou, CZ; Yu, LH; Xiang, CB. ATHB17 enhances stress tolerance by coordinating photosynthesis associated nuclear gene and ATSIG5 expression in response to abiotic stress. Sci Rep 2017, 7, 45492. https://doi.org/10.1038/srep45492.

29. Staneloni, RT; Rodriguez-Batiller, MJ; Casal, JJ. Abscisic acid, high-light, and oxidative stress down-regulate a photosynthetic gene via a promoter motif not involved in phytochrome-mediated transcriptional regulation. Mol Plant 2008, 1(1), 75-83. https://doi.org/10.1093/mp/ssm007

30. Liu, X; Zhang, R; Ou, H; Gui, Y; Wei, J; Zhou, H; Tan, H; Li, Y. Comprehensive transcriptome analysis reveals genes in response to water deficit in the leaves of Saccharum narenga (Nees ex Steud.) hack. BMC Plant Biol 2018, 18(1), 250. https://doi.org/10.1186/s12870-018-1428-9 
31. Zhang, Y; Kong, X; Dai, J; Luo, Z; Li, Z; Lu, H; Xu, S; Tang, W; Zhang, D; Li, W; Xin, C; Dong, H. Global gene expression in cotton (Gossypium hirsutum L.) leaves to water logging stress. PLoSONE 2017, 12(9), e0185075. https://doi.org/10.1371/journal.pone.0185075

32. Xu, YH; Liu, R; Yan, L; Liu, ZQ; Jiang, SC; Shen, YY; Wang, XF; Zhang, DP. Light-harvesting chlorophyll a/b-binding proteins are required for stomatal response to abscisic acid in Arabidopsis. J Exp Bot 2012, 63(3), 1095-1106. https://doi.org/10.1093/jxb/err315

33. Romero, FM; Maiale, SJ; Rossi, FR; Marina, M; Ruíz, OA; Gárriz, A. Polyamine metabolism responses to biotic and abiotic stress. Methods Mol Biol 2018, 1694, 37-49. https://doi.org/10.1007/978-1-4939-7398-9 3

34. Wu, G. Functional amino acids in growth, reproduction, and health. Adv Nutr 2010, 1(1), 31-37. https://doi.org/10.3945/an.110.1008

35. Hasanuzzaman, M; Alhaithloul, H; Parvin, K; Bhuyan, M; Tanveer, M; Mohsin, SM; Nahar, K; Soliman, MH; Mahmud, JA; Fujita, M. Polyamine Action under Metal/Metalloid Stress: Regulation of Biosynthesis, Metabolism, and Molecular Interactions. Int J Mol Sci 2019, 20(13), 3215. https://doi.org/10.3390/ijms20133215

36. Chen, D; Shao, Q; Yin, L; Younis, A; Zheng, B. Polyamine function in plants: metabolism, regulation on development, and roles in abiotic stress responses. Front Plant Sci 2019, 9, 1945. https://doi.org/10.3389/fpls.2018.01945

37. Marco, F; Busó, E; Lafuente, T; Carrasco, P. Spermine confers stress resilience by modulating abscisic acid biosynthesis and stress responses in Arabidopsis plants. Front Plant Sci 2019, 10, 972. https://doi.org/10.3389/fpls.2019.00972

38. Pál, M; Tajti, J; Szalai, G; Peeva, V; Végh, B; Janda, T. Interaction of polyamines, abscisic acid and proline under osmotic stress in the leaves of wheat plants. Sci Rep 2018, 8, 12839. https://doi.org/10.1038/s41598-018-31297-6

39. Wei, L; Wang, L; Yang, Y; Wang, P; Guo, T; Kang, G. Abscisic acid enhances tolerance of wheat seedlings to drought and regulates transcript levels of genes encoding ascorbate-glutathione biosynthesis. Front Plant Sci 2015, 6, 458. https://doi.org/10.3389/fpls.2015.00458.

40. Nascimento, FX; Rossi, MJ; Glick, BR. Ethylene and 1-Aminocyclopropane-1-carboxylate (ACC) in Plant-Bacterial Interactions. Front Plant Sci 2018, 9, 114. https://doi.org/10.3389/fpls.2018.00114

41. Vanderstraeten, L; Van Der Straeten, D. Accumulation and transport of 1-aminocyclopropane-1-carboxylic acid (ACC) in plants: current status, considerations for future research and agronomic applications. Front Plant Sci 2017, 8, 38. https://doi.org/10.3389/fpls.2017.00038

42. Tiwari, G; Duraivadivel, P; Sharma, S; Hariprasad, P. 1-Aminocyclopropane-1-carboxylic acid deaminase producing beneficial rhizobacteria ameliorate the biomass characters of Panicum maximum Jacq. by mitigating drought and salt stress. Sci Rep 2018, 8(1), 17513. https://doi.org/10.1038/s41598-018-35565-3

43. Eun, H; Ali, S; Jung, H; Kim, K; Kim, WC. Profiling of ACC synthase gene (ACS11) expression in Arabidopsis induced by abiotic stresses. Appl Biol Chem 2019, 62, 42. https://doi.org/10.1186/s13765-019-0450-4

44. Dubois, M; Van den Broeck, L; Inzé, D. The pivotal role of ethylene in plant growth. Trends Plant Sci 2018, 23(4), 311-323. https://doi.org/10.1016/j.tplants.2018.01.003

45. Wasternack, C; Hause, B. Jasmonates: biosynthesis, perception, signal transduction and action in plant stress response, growth and development. An update to the 2007 review in Annals of Botany. Ann Bot 2013, 111, 1021-1058. https://doi.org/10.1093/aob/mct067

46. Guruprasad, K; Reddy, BVB; Pandit, MW. Correlation between stability of a protein and its dipeptide composition: a novel approach for predicting in vivo stability of a protein from its primary sequence. Protein Eng Des Sel 1990, 4(2), 155-61. https://doi.org/10.1093/protein/4.2.155

47. Rogers, S; Wells, R; Rechsteiner, M. Amino acid sequences common to rapidly degraded proteins: the PEST hypothesis. Science 1986, 234(4774), 364-368. https://doi.org/10.1126/science.2876518

48. Bagag, A; Jault, JM; Sidahmed-Adrar, N; Réfrégiers, M; Giuliani, A; Le Naour, F. Characterization of hydrophobic peptides in the presence of detergent by photoionization mass spectrometry. PLoS One 2013, 8(11), e79033. https://doi.org/10.1371/journal.pone.0079033

49. Magwanga, RO; Lu, P; Kirungu, JN; Lu, H; Wang, X; Cai, X; Zhou, Z; Zhang, Z; Salih, H; Wang, K; Liu, F. Characterization of the late embryogenesis abundant (LEA) proteins family and their role in drought stress tolerance in upland cotton. BMC Genet 2018, 19(1), 6. https://doi.org/10.1186/s12863-017-0596-1

50. Wang, W; Vinocur, B; Shoseyov, O; Altman, A. Role of plant heat-shock proteins and molecular chaperones in the abiotic stress response. Trends Plant Sci 2004, 9: 244-252. https://doi.org/10.1016/j.tplants.2004.03.006

51. Rehem, BC; Bertolde, FZ; de Almeida, AF. Regulation of Gene Expression in Response to Abiotic Stress in Plants. Cell Metabolism - Cell Homeostasis and Stress Response, Paula Bubulya, IntechOpen 2012, https://doi.org/10.5772/26636.

52. Hailemichael, G; Catalina, A; González, MR; Martín, P. Relationships between water status, leaf chlorophyll content and photosynthetic performance in tempranillo vineyards. South African J Enol Vitic 2016, 37(2), 149-156. https://doi.org/10.21548/37-2$\underline{1004}$.

53. Ahmadikhah, A; Marufinia, A. Effect of reduced plant height on drought tolerance in rice. 3 Biotech $2016,6(2), 221$. https://doi.org/10.1007/s13205-016-0542-3

54. Nikolaeva, MK; Maevskaya, SN; Shugaev, AG; Bukhov, NG. Effect of drought on chlorophyll content and antioxidant enzyme activities in leaves of three wheat cultivars varying in productivity. Russ J Plant Physiol 2010, 57, 87-95. https://doi.org/10.1134/S1021443710010127 
55. Lai, Q; Zhi-yi, B; Zhu-Jun, Z; Qiong-Qiu, Q; Bi-Zeng, M. Effects of osmotic stress on antioxidant enzymes activities in leaf discs of PSAG12-IPT modified gerbera. J Zhejiang Univ Sci B 2007, 8(7), 458-464. https://doi.org/10.1631/jzus.2007.B0458

56. Ghaffari, H; Tadayon, MR; Nadeem, M; Cheema, M; Razmjoo, J. Proline-mediated changes in antioxidant enzymatic activities and the physiology of sugar beet under drought stress. Acta Physiol Plant 2019, 41, 23. https://doi.org/10.1007/s11738-019-2815$\underline{Z}$

57. Gaschler, MM; Stockwell, BR. Lipid peroxidation in cell death. Biochem Biophys Res Commun 2017, 482(3), 419-425. https://doi.org/10.1016/j.bbrc.2016.10.086

58. Correa-Aragunde, N; Foresi, N; Delladonne, M; Lamattina, L. Auxin induces redox regulation of ascorbate peroxidase 1 activity by s-nitrosylation/denitrosylation balance resulting in changes of root growth pattern of Arabidopsis. Journal of Experimental Botany 2013, 64, 3339-3349. https://doi.org/10.1093/jxb/ert172

59. Filiz, E; Ozyigit, II; Saracoglu, IA; Uras, ME; Sen, U; Yalcin, B. Abiotic stress-induced regulation of antioxidant genes in different Arabidopsis ecotypes: microarray data evaluation. Biotechnol Biotechnol Equip 2019, 33(1), 128-143. https://doi.org/10.1080/13102818.2018.1556120 